\title{
Tilapia Culture in South Latitudes: First Report of Successful Fattening in Hot Springs of Buenos Aires Province, Argentina
}

\author{
Damián Luis Castellini ${ }^{1,3}$, Aldo Nahuel Zanazzi ${ }^{1, *}$, Angelina Gorosito ${ }^{1,4}$, Enzo Damián \\ Tranier $^{1}$, María Fernández Subiela ${ }^{1}$ and Juan Carlos Mallo ${ }^{1,2}$ \\ ${ }^{1}$ Laboratorio de Acuicultura, Universidad Tecnológica Nacional-Facultad Regional Mar del Plata \\ (UTN-FRMdP), Mar del Plata 7600, Argentina \\ ${ }^{2}$ Comisión de Investigaciones Científicas Pcia. Bs.As. (CIC), La Plata 1900, Argentina \\ ${ }^{3}$ Laboratorio de Biotaxonomía Morfológica y Molecular de Peces, Instituto de Investigaciones \\ Marinas y Costeras (IIMyC), CONICET- UNMdP, Mar del Plata 7600, Argentina \\ ${ }^{4}$ Centro Nacional Patagónico (CENPAT), CONICET, Puerto Madryn 9120, Argentina
}

*Correspondence :

nahuelzanazzi@gmail.com

Received : 2020-06-17

Accepted : 2020-08-21

Keywords :

Hot spring, Nile tilapia, Fattening

\begin{abstract}
In the present work, the feasibility of fattening Oreochromis niloticus specimens on a pilot scale in a geothermal water resource located in the Southeast of the province of Buenos Aires was analyzed. Before placing the culture units, physical and chemical characteristics of hot spring were studied to evaluate its suitability for tilapia farming. In the experimental stage, two hundred specimens with an average weight of 14.5 $\pm 1.8 \mathrm{~g}$ were placed in two floating cages $(1.30 \mathrm{x} 1 \mathrm{x} 1 \mathrm{~m})(100$ individuals per cage) and they were harvested at 140 days. The specimens were fed 3 times a day with a commercial pelleted feed with a content of $35 \%$ of proteins. Monthly samplings were carried out to evaluate growth (weight and total length), survival, and water samples were collected to measure their physical-chemical characteristics. The results of the water analysis showed a high quality in the hot springs (Simplified Water Quality Index $=88$ ). The fattening results showed an average final weight of 423-435.9 g, a survival of 87-91\%, SGR 1.47-1.49\%/day and the FCR was estimated at 1.05-1.07 for each cage respectively. We can conclude that this hot spring has the necessary water conditions to obtain excellent weight gains during the fattening period for the $O$. niloticus specimens. The present study represents the first Nile tilapia culture in the southernmost thermal waters, setting a precedent for future ventures in the area.
\end{abstract}

\section{INTRODUCTION}

Over the past decades, tilapia culture has been widely developed around the world and Latin-America has not been the exception (FAO, 2020). In recent years, tilapia culture has increased in the aquaculture industry, the Nile tilapia Oreochromis niloticus is the species that currently represents $70 \%$ of this cichlid genus cultured worldwide (Fitzsimmons, 2004). However, tilapia culture in natural systems might be limited in higher latitudes where cold water is not suitable for its growth and survival. There is evidence that tilapia's activity and feeding become reduced when the temperature falls below $20{ }^{\circ} \mathrm{C}$ and fish stop feeding at 
temperatures below $16^{\circ} \mathrm{C}$, with temperatures above $26^{\circ} \mathrm{C}$ being optimal. (Azaza et al., 2008). Thus, using thermal waters in tilapia culture seems to be a good alternative, mainly in subtropical areas, where winter prevents their growth since this is a warm water species with a geographically limited distribution (Lund and Boyd, 2016). Dan and Little (2000) reported the possible utilization of geothermal waters in combination with other factors of control and management for the aquaculture development of these organisms.

In Argentina, tilapia culture is still incipient but has great potential due to the great freshwater resources. The production of $O$. niloticus reached 23.7 tons in 2019 and was mainly centralized in the North-East region of the country (Panné Huidobro, 2019), which has SubTropical climate conditions. Buenos Aires is the most populated province where there is an increased demand for food. However, owing to its winter low temperatures, tilapia culture is limited to intensive recalculating systems where the water temperature can be controlled but the production costs are increased. Fortunately, several natural hot springs are located in this province, which might be used as culture media to farm this specie. Thus, the present research aims to study the feasibility of $O$. niloticus fattening in a pilot-scale at geothermal water resource located in the South-East of Buenos Aires province. Likewise, hot springs water quality, and time required to reach commercial size were evaluated.

\section{METHODOLOGY}

\section{Place and Time}

This study was conducted in the "Complejo Termas de Médanos" situated in Médanos, Province of Buenos Aires, Argentina (3850.37'04" S - 62 44'21" W) (Fig.1). This place presents a continuous hot spring of approximately 90,000 L/h through a cooling system that flows into canals (100m long, 20m wide and an average depth of $1 \mathrm{~m}$ ). Previous to the growing trial, the water body quality was assessed during December 2012. The experiment was carried out from January to May of the following year.

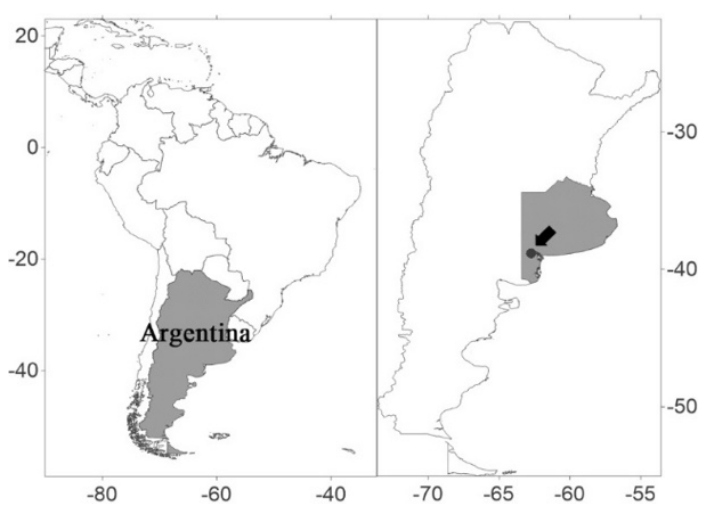

Figure 1. Location of the hot spring at Buenos Aires Province, Argentina.

\section{Research Material}

The tools used in the study include a water quality "Horiba U 10" multi-sensory, portable battery-operated fish tank aquarium air pump, plastic tanks, PVC floating cages, benzocaine, digital scale EK4150, ichtyometer and hand nets. The fish species used to support this study was Nile Tilapia (Oreochromis niloticus).

\section{Research Design}

Two hundred juveniles of Nile Tilapia (weight $14.5 \pm 1.8 \mathrm{~g}$, total length $9.8 \pm 0.8 \mathrm{~cm}$, standard length $7.5 \pm 0.6 \mathrm{~cm}$ ) were transported from the Aquaculture Laboratory (UTN-FRMdP) to the experimental facilities at "Complejo Termas de Medanos". On arrival, the fish were stocked in two plastic tanks of $100 \mathrm{~L}$ each, with constant aeration. Before 
farming, specimens were acclimated to the tank conditions. One hundred percent of the animals survived. Then, two P.V.C. frame cages (1,30 x $1 \times 1 \mathrm{~m})$ (Fig. 2) covered with $1 \mathrm{~cm}$ mesh nylon nets were built. In each cage, 100 juvenile tilapias were placed and the fattening trial started.

\section{Work Procedures}

\section{Evaluation of the Physical and Chemical Characteristics of Hot Springs}

First, a two-day campaign was conducted to evaluate water characteristics and suitability for tilapia culture. Sampling sites were located over the whole area of the water body (Fig. 3), to determine the most appropriate site for cages culture. In each sampling site, water quality parameters were recorded in situ (temperature, $\mathrm{pH}$, salinity, and $\mathrm{DO}$ ) at a depth of $50 \mathrm{~cm}$ using a "Horiba U 10" multi-sensory at different times (07:00 and $16: 00$ ) to observe the variations throughout the day. A water sample was also taken to determine the presence and amount of nutrients (nitrates, nitrites, unionized ammonia, phosphates, chlorophyll $a$ and $b$, etc.). Chemical determinations were conducted according to APHA (1998).

The results of water conditions measurement were used to evaluate the characteristics of the water body using the Simplified Water Quality Index (SWQI) (Bazzini, 2012; Ocampo-Duque et al., 2006). This index ranges from 0 (minimum quality) to 100 (maximum quality).

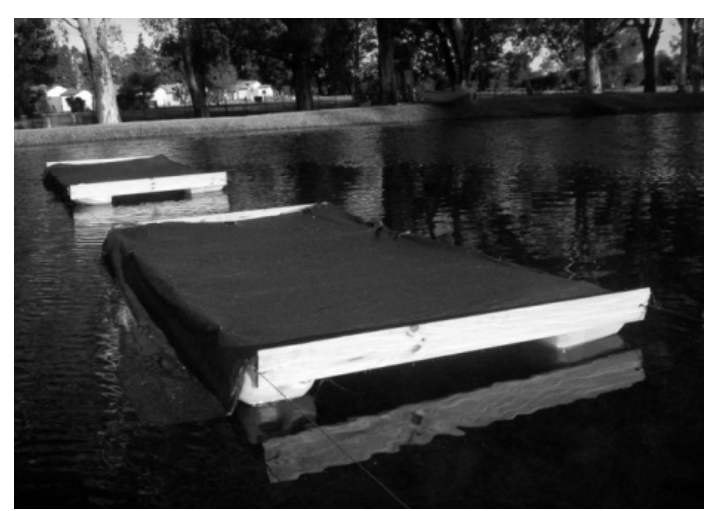

Figure 2. Floating cages employed during Nile tilapia fattening.

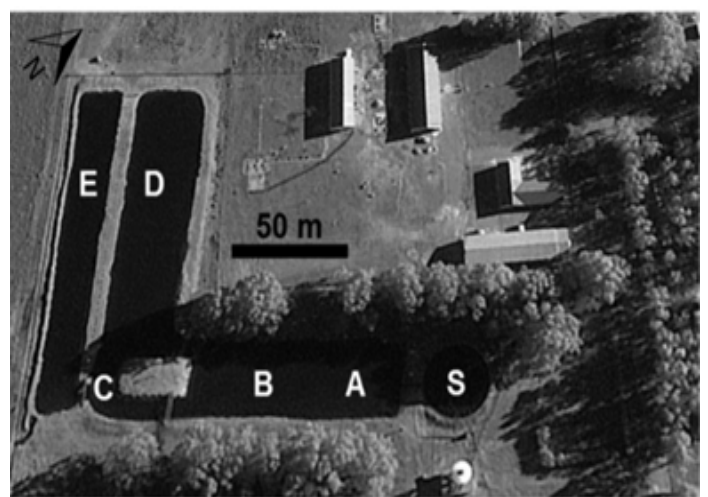

Figure 3. Location of the sampling sites "A", "B", "C", "D" and "E" defined in the water body. Cooling pool of the thermal spring "S".

\section{Feeding and Sampling Protocols}

The tilapia cultivation was carried out from January to May 2013. The nutritional requirements, amount of food and the feeding frequency were carried out according to Li et al. (2006), Riche et al. (2004), and Camacho-Berthely et al. (2000). The animals were fed with granulated commercial feed (Ganave S.A., 
Argentina) with $35 \%$ protein and grain size that varied from 5 to $10 \mathrm{~mm}$, this feed complies with what was suggested by the aforementioned authors. The daily feed ration was divided into three portions (08:00, 12:00, and 17:00 hs). The biomass of the cages was determined every month to adjust the amount of food.

Specimen sampling was carried out monthly to evaluate growth, survival, and diet adjustment. In each sampling, 30 individuals per cage were randomly captured, after fasting for $24 \mathrm{~h}$. The specimens were anesthetized with an aqueous solution of benzocaine (1:10000). Fish size and weights were recorded. In addition, temperature, $\mathrm{pH}$, and DO were determined in situ.

\section{Data Analysis}

Growth performance and feed utilization were assessed by the specific growth rate (SGR) and feed conversion ratio (FCR) as follows:

$\mathrm{SGR}=\frac{\ln F B W-\ln I B W}{\mathrm{~T}} \times 100$

Note:

FBW = final body weight $(\mathrm{g})$

IBW = initial body weight $(\mathrm{g})$

$\mathrm{FCR}=\frac{\mathrm{FI}}{\mathrm{WG}}$

Note:

FI $\quad$ feed intake $(\mathrm{g})$

WG = wet weight gain $(\mathrm{g})$

The SWQI is the function of 5 most relevant physical and chemical parameters as follow:

SWQI $=E(A+B+C+D)$

Note:

$\mathrm{E}$ = water temperature with values ranging from 0.8 to 1 according to:

$\mathrm{T} \leq 20^{\circ} \mathrm{C}, \mathrm{E}=1$

$\mathrm{T}>20^{\circ} \mathrm{C}, \mathrm{E}=1-(\mathrm{T}-20) \cdot 0.0125$

$\mathrm{A}=$ particulate organic matter $(\mathrm{POM})$ with values from $0-30$ according to:

$\mathrm{POM} \leq 5 \mathrm{mg} / \mathrm{L}, \mathrm{A}=30-\mathrm{POM}$

$12 \mathrm{mg} / \mathrm{L} \geq \mathrm{POM}>5 \mathrm{mg} / \mathrm{L}, \mathrm{A}=21$ -

$(0.35 \cdot \mathrm{POM})$

$\mathrm{POM}>12 \mathrm{mg} / \mathrm{L}, \mathrm{A}=0$

$\mathrm{B}$ = suspended particulate matter (SPM) with values ranging from 0 to 25 according to:

$\mathrm{SPM} \leq 100 \mathrm{mg} / \mathrm{L}, \mathrm{B}=25-(0.15 \cdot \mathrm{SPM})$
$250 \mathrm{mg} / \mathrm{L} \geq \mathrm{SPM}>100 \mathrm{mg} / \mathrm{L}, \mathrm{B}=17-$ (0.07·SPM)

$\mathrm{SPM}>250 \mathrm{mg} / \mathrm{L}, \mathrm{B}=0$

$\mathrm{C}=$ dissolved $\mathrm{O}_{2}(\mathrm{DO})$ with values ranging from 0 to 25 according to:

$\mathrm{DO}<10 \mathrm{mg} / \mathrm{L}, \mathrm{C}=2.5 \cdot \mathrm{O}_{2}$

$\mathrm{DO} \geq 10 \mathrm{mg} / \mathrm{L}, \mathrm{C}=25$

$\mathrm{D}=$ conductivity $\left(\mathrm{CE}\right.$ at $\left.18{ }^{\circ} \mathrm{C}\right)$. If conductivity is measured at $25{ }^{\circ} \mathrm{C}$, to obtain the conversion at $18{ }^{\circ} \mathrm{C}$ will be multiplied by 0.86 with values ranging from 0 to 20 according to:

$\mathrm{CE} \leq 4000 \mu \mathrm{S} / \mathrm{cm}, \quad \mathrm{D}=$

$\log \mathrm{CE}) \cdot 15.4$

$\mathrm{CE}>4000 \mu \mathrm{S} / \mathrm{cm}, \mathrm{D}=0$

Data on the individual weight recorded from each fish at the final sampling in both cages then compared to evaluate differences in the final weight gain using the Independent Samples t-Test (Sokal and Rohlf, 1995).

\section{RESULTS AND DISCUSSION Characterization of the Water Body}

Selection for sites is likely to be the most important factor to determine the viability of experiments in aquaculture projects, being water quality and availability also essential to optimize production.

The most relevant criteria of water quality are temperature, dissolved oxygen concentration, acidity, alkalinity, and $\mathrm{pH}$; however, the magnitude of these variable effects will depend on the species and the environmental conditions. The results of the campaign conducted in December 2012 showed that the water body the characteristics vary with the distance to the hot springs (Table 1 and Fig. 3). This variation is related to cooling undergone by water from the hot spring when it mixes with water in the pond. Parameter variation throughout the day does not show a wide range of values. In addition, the results of laboratory analysis on water quality do not show abnormal or dangerous (Table 2) (Bazzini, 2012). These findings demonstrate that water quality is suitable for the semi-intensive fish cage culture of $O$. niloticus because the physical and chemical parameters were at 
acceptable levels for the species (Azaza et

al., 2008; El-Sayed, 2019).

Table 1. Results of the physical and chemical analyses "in situ" of the sampling sites (A-

E) conducted during the evaluation of the physical and chemical characteristics of hot spring.

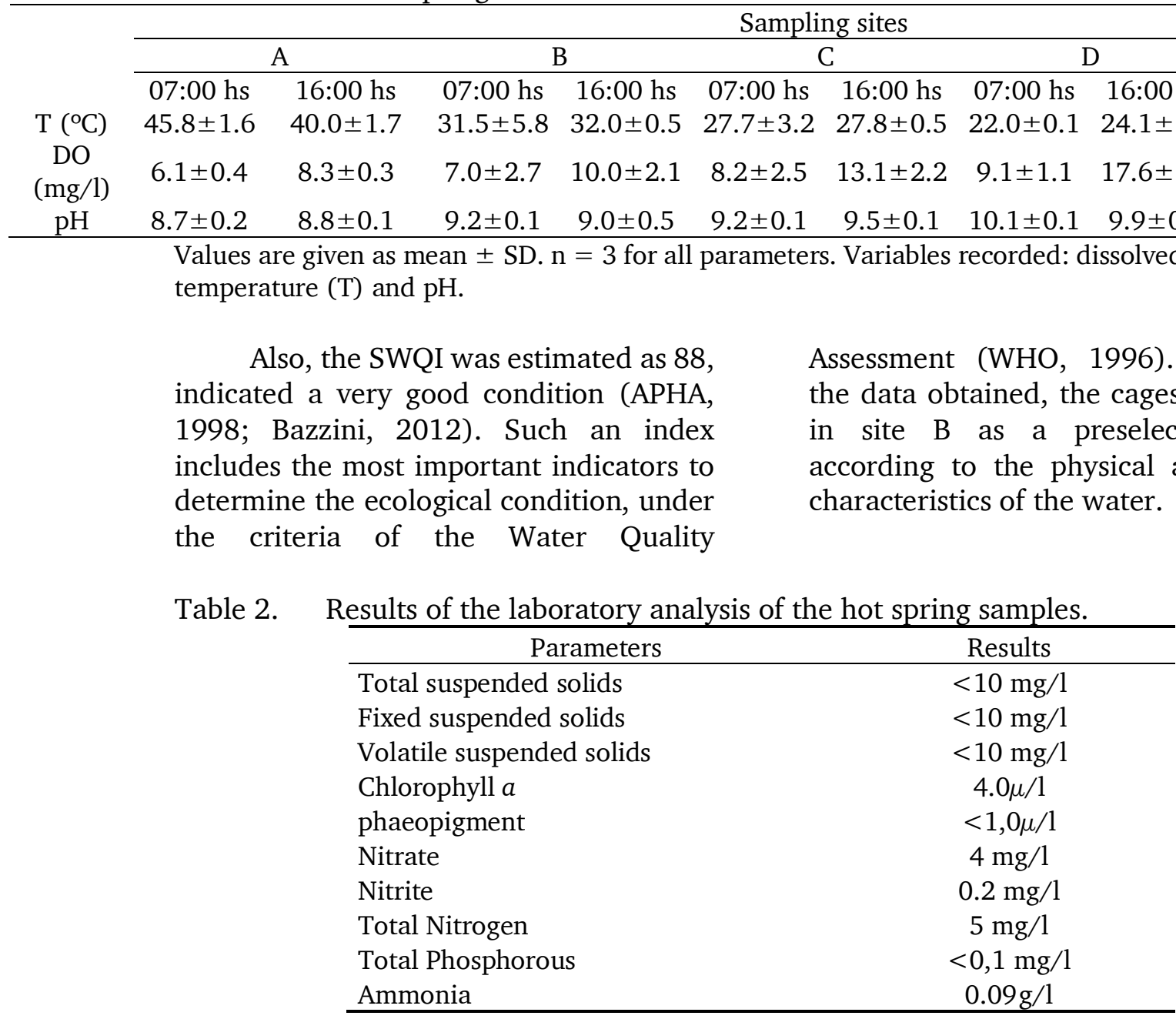

\section{Growth and Feed Utilization}

Tilapia specimens (Fig. 4) were harvested in May 2013, after 140 days of fattening. Table 3 shows the results recorded for each cage. A comparison of mean values obtained by the t-Test for final weights of the specimens in each cage showed no significant differences between cages $(\mathrm{p}=0.44 ; \mathrm{a}=0.05)$.
No differences were observed between the growth curves for each cage during the fattening period (Fig. 5). Harvested biomass was $39.8 \mathrm{~kg}$ and 39.1 $\mathrm{kg}$ for cages 1 and 2, respectively. The feeding rate in both cages ranged from 5\% to $1.5 \%$ of the biomass according to Camacho-Berthely et al. (2000). FCR was 1.05 and 1.07, while SGR was 1.47 and $1.49 \%$ /day for cages 1 and 2, respectively. 
Figure 4. Tilapia harvest.
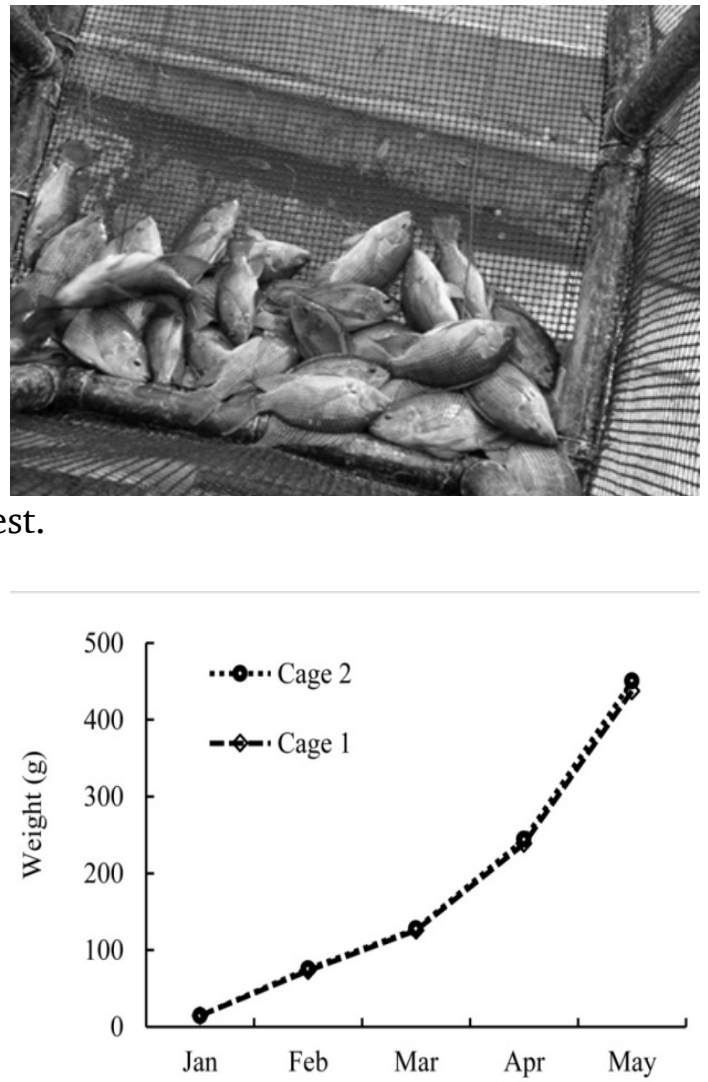

Figure 5. Growth curves in average weight throughout the experiment, fattening was carried out during 140 days. Model fit and quality indices.

Table 3. Tilapia O. niloticus weight, length, and survival at the end of the fattening trial.

\begin{tabular}{lccccc} 
& Weight $(\mathrm{g})$ & $\begin{array}{c}\text { Average weight } \\
\text { gain }(\mathrm{g})\end{array}$ & TL $(\mathrm{cm})$ & SL $(\mathrm{cm})$ & Survival (\%) \\
\cline { 2 - 6 } Cage 1 & $437.5 \pm 68.1$ & 423.0 & $27.9 \pm 1.6$ & $22.3 \pm 1.2$ & 91 \\
Cage 2 & $450.4 \pm 60.1$ & 435.9 & $28.1 \pm 1.8$ & $22.4 \pm 1.2$ & 87 \\
\hline
\end{tabular}

Values are given as mean \pm SD. $\mathrm{n}=30$. TL (Total Length), SL (Standard Length).

The SGR values obtained revealed an optimal fish growth. These values were higher than those reported by Ridha (2006) and Githukia et al. (2015) of 1.01 $\%$ /day and $1.47 \%$ /day, respectively. In addition, the FCRs observed in the present study indicate an excellent conversion compared with those reported by Ridha (2006), Githukia et al. (2015) and Ruiz Velazco Arce et al. (2006) of 1.40, 1.98 and 1.21 , respectively. Also, after 140 days of fattening the weights, lengths and survival obtained were suitable for the experimental period. Moreover, the comparison of these results with those reported in other papers on similar fattening systems indicates our results are highly satisfactory (Yi et al., 1996; Ruiz Velazco Arce et al., 2006) since it would be possible to perform at least to annual harvests. It should be highlighted that the present study represents the first Nile tilapia culture in thermal waters conducted in Argentina and the southernmost experimental culture of this species.

\section{CONCLUSION}

The experimental fattening carried out during 140 days revealed that the thermal waters of the analyzed region are suitable (temperature, $\mathrm{pH}$ and $\mathrm{DO}$ ) for cultivating Nile Tilapia, obtaining commercial weights in a short time. However, an experimental fattening of approximately one year should be carried out to observe the behavior of the species in terms of growth and survival at other 
times of the year and evaluate its feasibility on a larger scale.

\section{ACKNOWLEDGEMENT}

The present study was performed in response to a request from a local company (Covitur S.R.L.) that exploits a geothermal water resource located in the South-East of Buenos Aires province. The authors are grateful to Mr. Jorge Simoni (Covitur SRL) for his good predisposition and collaboration in the fieldwork carried out and to Lic. Juana Bau (Director of the Academic Unit Mar del Plata UTN) for the constant support of applied research since The Aquaculture Group. This study was financially supported by the UTN-FRMdP and Covitur S.R.L.

\section{REFERENCES}

American Public Health Association (APHA). 1998. Standard Methods for the examination of water and wastewater, American Water Works Association, Water Environmental Federation, 20th ed. Washington.

Azaza, M.S., Dhraïef, M.N. and Kraïem, M.M., 2008. Effects of water temperature on growth and sex ratio of juvenile Nile tilapia Oreochromis niloticus (Linnaeus) reared in geothermal waters in southern Tunisia. Journal of thermal Biology, 33(2), pp.98-105. https://doi.org/ 10.1016/j.jtherbio.2007.05.007

Bazzini, S., 2012. Evaluación del estado trófico y la calidad ambiental en humedales del sudeste bonaerense mediante el uso de indicadores. $\mathrm{PhD}$ thesis. Facultad de Ciencias Exactas y Naturales. Universidad Nacional de Mar del Plata. Argentina. 150pp.

Camacho-Berthely, E., Luna Romo, C. and Moreno Rodríguez, M.A., 2000. Guía para el cultivo de tilapia Oreochromis spp. (Gunter, 1984). Semarna. 136 pp.

Dan, N.C. and Little, D.C., 2000. Overwintering performance of Nile tilapia Oreochromis niloticus (L.) broodfish and seed at ambient temperatures in northern Vietnam. Aquaculture Research, 31(6), pp.485-493. https://doi.org/10.104 6/j.1365-2109.2000.00466.x

El-Sayed, A.F.M., 2019. Tilapia culture. Second Edition. Academic Press. $358 \mathrm{pp}$.

Fitzsimmons, K., 2004, September. Development of new products and markets for the global tilapia trade. In Proceeding of the Sixth International Symposium on Tilapia in Aquaculture, Manila, Philippines (pp. 624-633). https://cals.arizona. edu/azaqua/ista/ista6/ista6web/pr esentation/p624.pdf

Food and Agriculture Organization (FAO). 2020. El estado mundial de la pesca y la acuicultura, 2020. La sostenibilidad en acción. Roma. https://doi.org/10.4060/ca9229es

Githukia, C.M., Ogello, E.O., Kembenya, E.M., Achieng, A.O., Obiero, K.O., and Munguti, J.M., 2015. Comparative growth performance of male monosex and mixed sex Nile tilapia (Oreochromis niloticus L.) reared in earthen ponds. Croatian Journal of Fisheries: Ribarstvo, 73(1), pp. 20-25. https://doi.org/ 10.14798/73.1.788

Li, M.H., Lim, C.E. and Webster, C.D., 2006. Feed formulation and manufacture. Tilapia: Biology, culture and nutrition. CE Lim and CD Webster (Eds). The Haworth Press, Inc., New York, pp. 517-559.

Lund, J.W. and Boyd, T.L., 2016. Direct utilization of geothermal energy 2015 worldwide review. Geothermics, 60, pp.66-93. https:// doi.org/10.1016/j.geothermics.201 5.11 .004

Ocampo-Duque, W., Ferre-Huguet, N., Domingo, J.L. and Schuhmacher, M., 2006. Assessing water quality in rivers with fuzzy inference systems: A case study. Environment International, 32(6), pp.733-742. https://doi.org/10.1016/j.envint.2 006.03.009 
Panné Huidobro, S., 2019. Producción por Acuicultura en Argentina en el 2019. Dir. Acuic. Subsecr. Pesca Acuic. Minist. Agroind. https://www.agro industria.gob.ar/sitio/areas/acuicul tura/publicaciones

Riche, M., Haley, D.I., Oetker, M., Garbrecht, S. and Garling, D.L., 2004. Effect of feeding frequency on gastric evacuation and the return of appetite in tilapia Oreochromis niloticus (L.). Aquaculture, 234(1-4), pp. 657-673. https://doi.org/10.10 16/j.aquaculture.2003.12.012

Ridha, M.T., 2006. Comparative study of growth performance of three strains of Nile tilapia, Oreochromis niloticus, L. at two stocking densities. Aquaculture Research, 37(2), pp.172-179. https://doi.org/ 10.1111/j.1365-2109.2005.01415.x

Ruiz Velazco Arce, J.M.deJ., R. Tapia Varela, R., García Partida, J.R. and González Vega, H., 2006. Evaluación de un cultivo semiintensivo de tilapia (Oreochromis niloticus) en tanques circulares con aguas termales (Evaluation of a semi-intensive farming of tilapia (Oreochromis niloticus) in circular tanks with thermal waters). Revista Electrónica de Veterinaria Vol. VII, No 11. https://www.redalyc.org/articu lo. oa?id $=63612653020$

Sokal, R.R. and Rohlf, F.J., 1995. Biometry: The principles and practice of statistics in biological research. 3rd edition. W.H. Freeman, New York. $887 \mathrm{pp}$.

WHO, 1996. Water quality asessments - a guide to use of biota, sediments and water in environmental monitoring. Second Edition. F and FN Spon. Printed in Great Britain at the University Press, Cambridge. 651 pp.

Yi, Y., Lin, C.K. and Diana, J.S., 1996. Influence of Nile tilapia (Oreochromis niloticus) stocking density in cages on their growth and yield in cages and in ponds containing the cages. Aquaculture,
146(3-4), pp.205-215. https://doi. org/10.1016/S0044-8486(96)0137 7-4 